\title{
RECYCLING WOOD WASTE FROM CONSTRUCTION AND DEMOLITION TO PRODUCE PARTICLEBOARDS
}

\author{
Rafael da Rosa Azambuja ${ }^{1, \diamond}$, Vinicius Gomes de Castro ${ }^{2}$, Rosilani Trianoski, \\ Setsuo Iwakiri ${ }^{3}$
}

\begin{abstract}
The objective of this study was to evaluate the feasibility of construction and demolition (C\&D) waste wood to produce of particleboard. The raw material was obtained from a waste recycling company and it was divided into four types of materials: MDF (medium density fiberboard), MDP (medium density particleboard), plywood and timber. After reduction of these wood product residues to particles, particleboards were produced, in the UFPR Laboratory, with urea-formaldehyde resin and a target density of $0,75 \mathrm{~g} / \mathrm{cm}^{3}$ and their physical and mechanical properties were determined. Particleboards made from industrial Pinus spp. particles were also produced as control samples. C\&D wood waste showed potential for use as raw material for particleboard. The properties of particleboard made of recycled timber, MDP, plywood and the mixture of the four sources of material indicated that particleboard industries could use these waste resources for the production of the inner layer of MDP products.
\end{abstract} residue.

Keywords: Mechanical properties, physical properties, urea-formaldehyde, wood panels, wood

\section{INTRODUCTION}

Municipal solid waste (MSW) is the waste generated not only from domestic, commercial activities and the general population but also produced by the construction and demolition sector. The MSW per capita has been increased worldwide and became a major environmental threat (Karak et al. 2012). The MSW generated in Brazil in 2015 was approximately 80 million tons 10,2\% higher when compared to the previous year, and the Construction and Demolition (C\&D) waste represented a considerable part $(56,3 \%)$ of this total (Abrelpe 2016). C\&D waste can be defined as the waste from building debris, rubble, earth, concrete, steel, timber, site clearance materials, construction erection, renovation and demolition activities (Shen et al. 2004).

C\&D waste is unavoidable and implementing "zero waste" management would be impractical, so it became critical to pursue solutions to waste reduction, reuse, recycling and disposal (Yuan and Shen 2011). The current Brazilian legislation delegates, since 2002, a chain of responsibilities for C\&D generators. It is an obligation of the generator to minimize the C\&D waste and at the same time propose waste reuse or recycling actions. The legislation also classifies timber and wood products as a C\&D waste component that has its reuse limited if the material is contaminated by environmentally harmful materials, such as dyes, mold release agents or chemical preservative treatments (CONAMA 2002).

\footnotetext{
${ }^{1}$ Division of Forestry and Natural Resources, West Virginia University, Morgantown, WV, USA.

${ }^{2}$ Departamento de Ciências Vegetais, Universidade Federal Rural do Semi-Árido, Mossoró, RN, Brasil; ${ }^{3}$ Departamento de Engenharia e Tecnologia Florestal, Universidade Federal do Paraná, Curitiba, PR, Brasil.

"Corresponding author: rafael.r.azambuja@gmail.com

Received: 17.07.2017 Accepted: 26.05.2018
} 
The amount and composition of C\&D waste depend on its origins as it is associated with regional construction techniques and material types. The range of wood products in the United States C\&D waste was estimated to be 6-7\% (Cochran and Townsend 2010), while in Brazil, the amount of wood can be even higher, 10-16\% (Miranda et al. 2009).

Recycling of C\&D waste is already common practice in most EU countries. Denmark, Germany, Ireland, Netherlands, and Estonia recycle over $80 \%$ of C\&D waste generation, while Austria, Belgium, France, Lithuania and the UK reaches $60-70 \%$ (Saez et al. 2011). The United States adopted a system of incentives for reducing material that is destined for landfills, examples are the cities of Portland (OR) and Austin (TX) which are recycling $75 \%$ and $90 \%$ of their C\&D waste, respectively (Laquatra and Pierce 2014). In Brazil, the scenario is worse, if all recycling companies were operating at full capacity, even then the estimate would be that only 4,5\% of C\&D waste could be recycled (Miranda et al. 2009).

A researched option for the use of wood waste in C\&D is the production of particleboards from this residue. Yang et al. (2007) produced phenol formaldehyde particleboards with mixtures of Quercus spp. and Shorea spp. from C\&D wastes from Taiwan, obtaining some physical-mechanical properties higher than conventionally manufactured particleboard. Although the species that the author used are not commonly used in western construction, such as pine and eucalyptus, this indicates potential for the use of the material into particleboards. Reutilization of wood to produce particleboards was the topic of Weber (2011), the author used wood particles disposed from a mill line production to be recycled into new panels. The utilization of wood from C\&D was approached by Hossain and Poon (2018), between the scenarios presented by the authors, the production of particleboards presented the least environmental impact by the release of greenhouse gases.

Thus, timber and wood products from Brazilian C\&D waste have a potential value still unexploited by industries. The use of recycled material also attends to growing demand for environmentally friendly products. But also considering that the lignocellulosic materials of particleboards are responsible for the physical-mechanical properties, the choice of woody material is fundamental for the final product (Melo et al. 2015). Therefore, the aim of this work was to evaluate the mechanical and physical feasibility of using timber and wood products from C\&D waste as raw material to produce particleboard.

\section{MATERIAL AND METHODS}

Particleboards were produced with C\&D waste timber and wood products collected in the metropolitan region of Curitiba, Brazil. The material was segregated into four classes according to its origin: MDF, MDP, plywood and timber. The collected waste was processed initially in an industrial grinder, followed by a hammer mill and classified by automatic sieving. The particles retained between 8 and 14 mesh sieves were dried to an average moisture content of $3 \%$.

Length, thickness and width of 100 random particles from each source were measured by a digital caliper. Slenderness ratio (length/thickness), flatness ratio (width/thickness) and particle surface area (calculated by the equation suggested by Moslemi (1974), adapting the density of the material for the apparent bulk density) were determined. The bulk density was obtained on an adaptation using the basis of the procedures described in the Brazilian Standard ABNT-NBR 6922 :1983, whose volume was determined in a 2 liters' test tube and mass obtained using a digital scale.

Six types of particleboards were produced: one for each class of C\&D waste, one mix at the ratio of $25 \%$ of each residue, and one control sample manufactured with Pinus spp. particles obtained in a particleboard industry. Urea-formaldehyde resin (UF) was applied at $8 \%$ based on oven dry weight. One percent ammonium sulfate was added in the resin as a hardener and $1 \%$ paraffin wax emulsion was applied to reduce the particles hygroscopicity. The target density was $0,75 \mathrm{~g} / \mathrm{cm}^{3}$ and three panels were made for each treatment. The dimensions of particleboard were $50 \times 50 \times 1,5 \mathrm{~cm}$. Press temperature was 
$160^{\circ} \mathrm{C}$, pressure was $4 \mathrm{MPa}$ and pressing time was 8 minutes.

Physical and mechanical properties were evaluated based on European and Brazilian standards: apparent density (EN 323:1993); water absorption and thickness swelling after 2 and 24 hours of immersion (EN 317:2002); moisture content (EN 322:1993), module of elasticity in bending and bending strength (EN 310:2002); transverse tensile strength perpendicular to the plane (EN 319:2002); face and edge screw withdrawn resistance (ABNT-NBR 14810-2:2006).

Data for physical and mechanical properties were fitted in a completely randomized design and evaluated by analysis of covariance (ANCOVA) using the density value as the covariate using Statgraphics Centurion XV.II software. Then the treatment means were ranked by Tukey test $(\alpha=0,05)$.

\section{RESULTS AND DISCUSSION}

\section{Particle characterization}

Particle sizes used as raw material are presented in Table 1 . However, it was not feasible to determine MDF particles' dimension due to their wood fiber composition origin. During the hammer mill process, a great amount of the MDF particles were defibred to a degree that became impossible to measure their dimensions. Thus, the only information collected from this material was its bulk density.

Table 1: Dimensional elements and bulk density of particles.

\begin{tabular}{|c|c|c|c|c|c|c|c|c|}
\hline Material & $\mathbf{L}(\mathbf{m m})$ & $\begin{array}{c}\mathrm{W} \\
(\mathrm{mm})\end{array}$ & $\begin{array}{c}\mathrm{T} \\
(\mathrm{mm})\end{array}$ & $\begin{array}{c}\mathbf{V} \\
\left(\mathrm{mm}^{3}\right)\end{array}$ & SR & FR & $\mathrm{SA}\left(\mathrm{cm}^{2} / \mathrm{g}\right)$ & $\mathrm{BD}\left(\mathrm{g} / \mathrm{cm}^{3}\right)$ \\
\hline Pinus & 7,529 & 1,728 & 0,583 & $\begin{array}{l}8,235 \mathrm{a} \\
(78,7) \\
\end{array}$ & $\begin{array}{l}16,70 a \\
(66,6)\end{array}$ & $\begin{array}{l}5,21 \mathrm{~cd} \\
(68,5)\end{array}$ & \begin{tabular}{|l|}
$341,14 a$ \\
$(56,2)$
\end{tabular} & $\begin{array}{l}0,1835 d \\
(2,87)\end{array}$ \\
\hline MDF & - & - & - & - & - & - & - & $\begin{array}{l}0,1139 \mathrm{e} \\
(3,50)\end{array}$ \\
\hline MDP & 7,744 & 1,418 & 0,769 & $\begin{array}{l}9,040 \mathrm{a} \\
(75,0)\end{array}$ & $\begin{array}{l}11,52 d \\
(60,0)\end{array}$ & $\begin{array}{l}5,01 d \\
(46,3)\end{array}$ & $\begin{array}{l}174,78 \mathrm{c} \\
(37,0)\end{array}$ & $\begin{array}{l}0,2759 a \\
(1,54)\end{array}$ \\
\hline Plywood & 7,212 & 1,616 & 0,752 & $\begin{array}{l}9,164 a \\
(63,2)\end{array}$ & $\begin{array}{l}12,58 \mathrm{~cd} \\
(70,9)\end{array}$ & $\begin{array}{l}6,47 \mathrm{bc} \\
(58,6)\end{array}$ & \begin{tabular}{|l}
$214,81 b c$ \\
$(43,1)$
\end{tabular} & $\begin{array}{l}0,2384 \mathrm{c} \\
(0,86)\end{array}$ \\
\hline Timber & 8,203 & 1,392 & 0,661 & $\begin{array}{l}7,816 a \\
(69,8)\end{array}$ & $\begin{array}{l}14,75 \mathrm{bc} \\
(52,7)\end{array}$ & $\begin{array}{l}7,10 \mathrm{a} \\
(57,9)\end{array}$ & $\begin{array}{l}220,56 b \\
(36,2)\end{array}$ & $\begin{array}{l}0,2495 b \\
(4,64)\end{array}$ \\
\hline
\end{tabular}

L: length; W: width; T: thickness; V: volume; SR: slenderness ratio; FR: flatness ratio; SA: superficial area; BD: bulk density; Values in brackets indicate the coefficient of variation (\%); Means values followed by the same letter within the same column do not differ statistically in probability level of $95 \%$ by Tukey test.

Slenderness ratio (SR) from control samples (Pinus spp) was statistically higher than the other material, meanwhile samples produced with recycled MDP and plywood showed lower average values. Both MDP and plywood samples had adhesive in their original composition. The presence of this residue adhesive on the particle surface could be responsible for the production of higher thickness particles that resulted in lower SR values. The residue adhesive also influenced the flatness ratio (FR) result, but in a different way. FR values from recycled timber were higher than the values found for particles produced with other C\&D waste material or the control sample. Recycled timber, without adhesive, presented with lower width values than the samples originated from already processed material.

There were significant differences among all surface area (SA) and bulk density (BD) values of the samples. Particles of Pinus spp used at a traditional particleboard industry showed a statistically higher SA value than particles produced from $C \& D$ waste, as a consequence of a lower $B D$ of the sample. Higher BD of recycled MDP and plywood can be explained by the presence of adhesive and other chemical additives used in the manufacturing of the original product. The higher $\mathrm{BD}$ of recycled timber 
when compared with Pinus timber can be explained not only by the presence of contaminants, but also by its composition with different species of hardwoods and softwoods. However, recycled MDF particles were the material with the lowest BD value. According to Vale et al. (2011) materials with bulk density values close to $0,1 \mathrm{~g} / \mathrm{cm}^{3}$ can be considered as light. Even with the methodology applied to determine the SA, it was not possible to measure the SA of MDF particles, it was assumed that this kind of material has high surface area as a result of its particle size.

\section{Physical properties of the particleboards}

The physical properties of the panels evaluated were water absorption and swelling in thickness and measured in periods of 2 and 24 hours in submersion. The results of these tests are presented in the Table 2.

Table 2: Physical properties of the particleboards.

\begin{tabular}{|c|c|c|c|c|c|}
\hline Raw material & $\begin{array}{c}\mathbf{D} \\
\left(\mathbf{g} / \mathbf{c m}^{\mathbf{3}}\right)\end{array}$ & $\begin{array}{c}\text { WA 2h } \\
\mathbf{( \% )}\end{array}$ & $\begin{array}{c}\text { WA 24h } \\
\mathbf{( \% )}\end{array}$ & $\begin{array}{c}\text { TS 2h } \\
\mathbf{( \% )}\end{array}$ & $\begin{array}{c}\text { TS 24h } \\
\mathbf{( \% )}\end{array}$ \\
\hline \multirow{2}{*}{ 1. Pinus } & $0,71 \mathrm{~b}$ & $24,46 \mathrm{c}$ & $70,47 \mathrm{a}$ & $7,49 \mathrm{~b}$ & $23,16 \mathrm{ab}$ \\
& $(5,40)$ & $(7,36)$ & $(11,70)$ & $(25,79)$ & $(24,01)$ \\
\hline \multirow{2}{*}{$2 . \mathrm{MDF}$} & $0,71 \mathrm{~b}$ & $30,76 \mathrm{~b}$ & $73,62 \mathrm{a}$ & $7,36 \mathrm{bc}$ & $21,27 \mathrm{ab}$ \\
& $(5,25)$ & $(32,76)$ & $(39,37)$ & $(18,87)$ & $(19,45)$ \\
\hline \multirow{2}{*}{ 3. MDP } & $0,69 \mathrm{ab}$ & $17,32 \mathrm{~d}$ & $44,41 \mathrm{~b}$ & $5,77 \mathrm{~cd}$ & $15,16 \mathrm{c}$ \\
& $(5,62)$ & $(18,87)$ & $(32,76)$ & $(19,45)$ & $(39,37)$ \\
\hline \multirow{2}{*}{ 4. Plywood } & $0,67 \mathrm{a}$ & $37,68 \mathrm{a}$ & $79,40 \mathrm{a}$ & $9,42 \mathrm{a}$ & $26,71 \mathrm{a}$ \\
& $(3,20)$ & $(15,83)$ & $(8,61)$ & $(34,19)$ & $(13,77)$ \\
\hline \multirow{2}{*}{ 5.Timber } & $0,71 \mathrm{~b}$ & $20,11 \mathrm{~d}$ & $48,92 \mathrm{~b}$ & $5,04 \mathrm{~d}$ & $15,35 \mathrm{c}$ \\
& $(4,67)$ & $(10,76)$ & $(8,80)$ & $(24,81)$ & $(10,34)$ \\
\hline \multirow{2}{*}{ 6. Mix } & $0,75 \mathrm{c}$ & $17,40 \mathrm{~d}$ & $52,94 \mathrm{~b}$ & $5,46 \mathrm{~d}$ & $16,12 \mathrm{c}$ \\
& $(5,17)$ & $(13,52)$ & $(8,82)$ & $(18,40)$ & $(11,17)$ \\
\hline
\end{tabular}

D: density; WA $2 \mathrm{~h}$ and WA 24h: water absorption after 2 and 24 hours; TS $2 \mathrm{~h}$ and TS 24h: thickness swelling after 2 and 24 hours; Values in brackets indicate the coefficient of variation (\%); Means values followed by the same letter within the same column do not differ statistically in probability level of $95 \%$ by Tukey test. Values adjusted by ANCOVA to the mean density of the specimens $0,707 \mathrm{~g} / \mathrm{cm}^{3}$.

The particleboards final density ranged from $0,67 \mathrm{~g} / \mathrm{cm}^{3}$ to $0,75 \mathrm{~g} / \mathrm{cm}^{3}$, with statistically significant difference (Table 2). Only when the mixture of all C\&D waste was used as raw material, did the final particleboard reach the target density $\left(0,75 \mathrm{~g} / \mathrm{cm}^{3}\right)$. The lower density from the other treatments can be attributed to springback after the boards pressing and acclimatization to the equilibrium moisture content of $12 \%$.

Water absorption (WA) average values after 2 and 24 hours of immersion for particleboards made of recycled MDP, timber and the mixture of different $C \& D$ waste were lower than the control particleboard and treatments made of recycled MDF and plywood. Thickness swelling (TS) values after 24 hours were also statistically lower for the same group of particleboards with lower WA. After 2 hours of immersion, TS values of the particleboards, with the exception of the ones produced with recycled plywood, met the $8 \%$ minimum requirement of the European standard (EN 317 2002). Although after 24 hours of immersion, none of the treatments met the minimum requirement of $15 \%$ (Figure 1). 

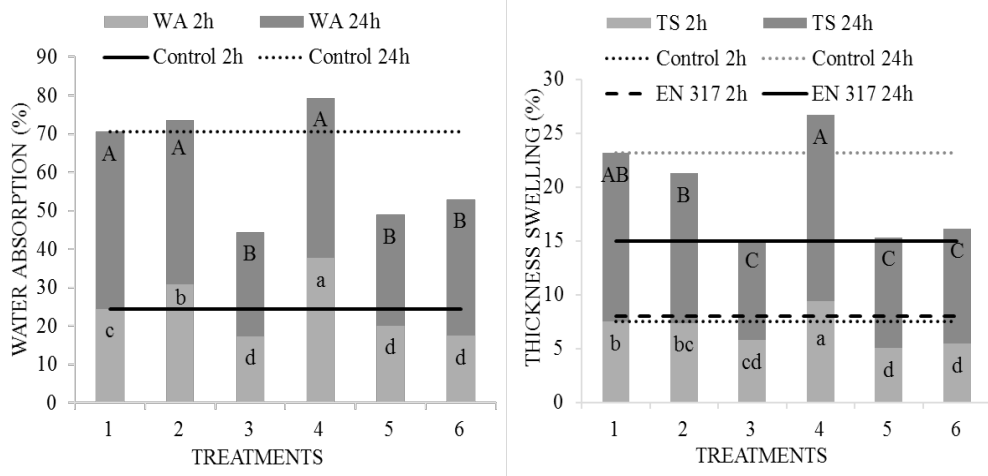

Figure 1: Physical properties of the particleboards.

Despite the fact that the TS values didn't achieve the standard requirement, particleboards from recycled MDP, timber and waste mixture were lower than results reported for particleboards made of recycled material. Lykidis and Grigoriou (2008) tested particleboards made of recovered wood particles and reported TS values after $24 \mathrm{~h}$ immersion ranged from 37,03 to $59,11 \%$. Nourbakhsh and Ashori (2010) produced particleboard with a mixture of poplar (Populus deltoides) wood and 50 or $75 \%$ of waste newspaper and reported TS values between 20,5 and $25,9 \%$ depending on the press temperature. Weber and Iwakiri (2015) reported TS values of 16,65 and 32,26\% for particleboards produced with recycled MDP and plywood, respectively.

\section{Mechanical properties of the panels}

The results of the bending test, internal bond (IB) and face and edge screw withdrawn are shown in Table 3.

Table 3: Results of the mechanical tests.

\begin{tabular}{|c|c|c|c|c|c|}
\hline \multirow{2}{*}{ Raw Material } & \multicolumn{2}{|c|}{ Static Bending } & \multirow{2}{*}{ IB (MPa) } & \multirow{2}{*}{ FSW (N) } & \multirow{2}{*}{$\operatorname{ESW}(\mathbf{N})$} \\
\hline & MOE (MPa) & MOR (MPa) & & & \\
\hline 1. Pinus & $\begin{array}{l}1378 \mathrm{a} \\
(15,77)\end{array}$ & $\begin{array}{l}8,00 \mathrm{~b} \\
(20,83)\end{array}$ & $\begin{array}{l}0,91 \mathrm{a} \\
(10,21)\end{array}$ & $\begin{array}{l}1183 \mathrm{a} \\
(13,16)\end{array}$ & $\begin{array}{l}1139 \mathrm{a} \\
(11,69)\end{array}$ \\
\hline 2. MDF & $\begin{array}{l}497 d \\
(35,07)\end{array}$ & $\begin{array}{l}4,59 \mathrm{~d} \\
(34,41)\end{array}$ & $\begin{array}{l}0,18 \mathrm{~d} \\
(15,06)\end{array}$ & $\begin{array}{l}466 \mathrm{e} \\
(24,50)\end{array}$ & $\begin{array}{l}341 \mathrm{e} \\
(21,40)\end{array}$ \\
\hline 3. MDP & $\begin{array}{l}1013 c \\
(23,74)\end{array}$ & $\begin{array}{l}6,49 c \\
(26,08)\end{array}$ & $\begin{array}{l}0,75 b \\
(16,21)\end{array}$ & $\begin{array}{l}794 c \\
(16,60)\end{array}$ & $\begin{array}{l}606 d \\
(17,48)\end{array}$ \\
\hline 4. Plywood & $\begin{array}{l}1299 \mathrm{a} \\
(15,99)\end{array}$ & $\begin{array}{l}7,12 \mathrm{bc} \\
(14,42)\end{array}$ & $\begin{array}{l}0,36 \mathrm{c} \\
(14,99)\end{array}$ & $\begin{array}{l}735 d \\
(11,22)\end{array}$ & $\begin{array}{l}571 d \\
(14,87)\end{array}$ \\
\hline 5. Timber & $\begin{array}{l}1392 \mathrm{a} \\
(16,95)\end{array}$ & $\begin{array}{l}9,69 \mathrm{a} \\
(21,11)\end{array}$ & $\begin{array}{l}0,96 \mathrm{a} \\
(12,33)\end{array}$ & $\begin{array}{l}940 \mathrm{~b} \\
(14,07)\end{array}$ & $\begin{array}{l}865 \mathrm{~b} \\
(16,00)\end{array}$ \\
\hline 6. Mix & $\begin{array}{l}1144 b \\
(18,91)\end{array}$ & $\begin{array}{l}7,19 \mathrm{bc} \\
(31,54)\end{array}$ & $\begin{array}{l}0,76 \mathrm{~b} \\
(15,90)\end{array}$ & $\begin{array}{l}808 c \\
(20,19)\end{array}$ & $\begin{array}{l}758 \mathrm{c} \\
(14,80)\end{array}$ \\
\hline
\end{tabular}

MOE: Modulus of Elasticity in bending; MOR: Modulus of Rupture in bending; IB: Internal Bond; FSW: Face screw withdrawal; ESW: Edge screw withdrawal; Values in brackets indicate the coefficient of variation (\%); Mean values followed by the same letter within the same column do not differ statistically in probability level of $95 \%$ by Tukey test.

Values adjusted by ANCOVA to the mean density of the specimens according to the tests: $0,680 \mathrm{~g} / \mathrm{cm}^{3}$ for MOE and MOR; $0,705 \mathrm{~g} / \mathrm{cm}^{3}$ for IB; $0,675 \mathrm{~g} / \mathrm{cm}^{3}$ for SWS and $0,636 \mathrm{~g} / \mathrm{cm}^{3}$ for SWT. 
Particleboards produced with recycled plywood and timber had MOE average values statistically similar to the control sample and higher than the other treatments. For MOR property, the use of recycled timber resulted in an average value statistically higher than the one for particleboards made with industrial Pinus particles. This result could be associated with the slenderness ratio of the recycled timber particles, once higher slenderness ratio usually is associated with better bending results (Moslemi 1974, Maloney 1993).
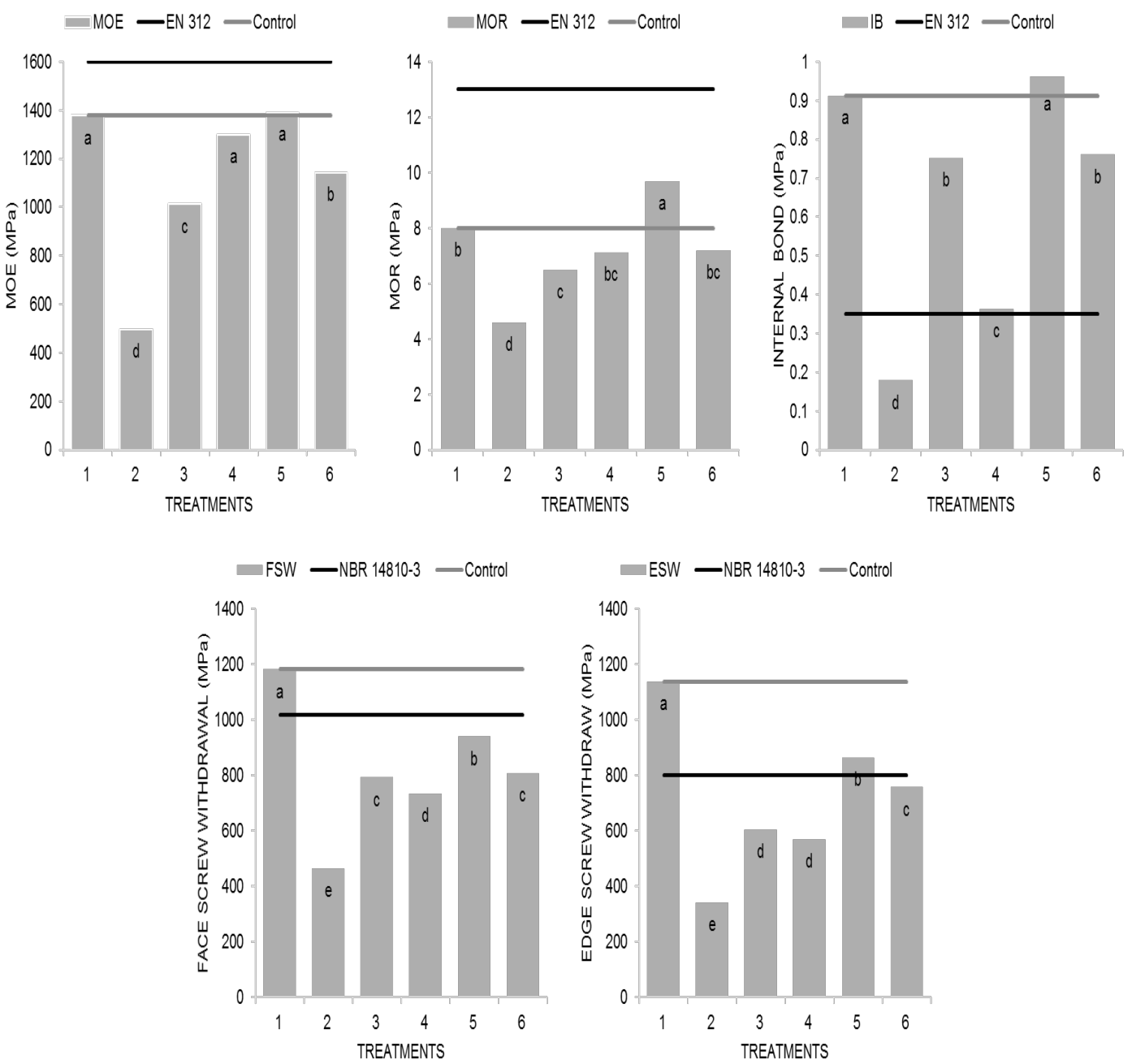

Figure 2: Results of the mechanical tests of the particleboards.

Where: Treatments are: 1: Pinus; 2: MDF; 3: MDP; 4: Plywood; 5: Timber; 6: Mixture

None of the evaluated treatments met the standard requirement from EN 312:2003, of $1600 \mathrm{MPa}$ for MOE and $13 \mathrm{MPa}$ for MOR. It is noteworthy that this study used construction and demolition wood waste, which can be considered materials in the end of their life cycle. Also, the previous uses of these products can cause contaminations that can cause negative influences in the particles production and 
the glue bond of the panel.

Considering the control as the particle used in industry to produce MDP panels, it can be admitted as the minimal industry quality. The difference between standard and the control can be explained as a consequence of different production in laboratory and industry. That way it can be said that the treatments that were equal or higher than the control possesses potential for production on an industrial scale. The treatments that overcome control values were 4 and 5, plywood waste and timber waste, respectively.

An alternative to increase the bending resistance (MOE and MOR) of the particles used in this research is to change the methods of particle production. This change in process should aim to produce thinner particles. Vital et al. (1992) and Alves (2013), state that the particles decreasing of thickness results in a better distribution of tension inside the panel, this is because there is reduction of voids and consequently better resistance to bending in the panels.

The average values of internal bond varied from 0,18 MPa (MDF waste) to 0,96 MPa (timber waste). The particles of timber waste produced panels with IB statistically equal to the Pinus control panels. Except for panels produced with residue of MDF, all the other panels achieve the EN 312:2003 requirements of 0,35 MPa. Candan and Akbulut (2015) using nanoreinforcement in particleboards, produced panels with internal bonding bellow $0,4 \mathrm{MPa}$, lower results than the ones found in MDP, timber and the mixture of residues. Also, the low superficial area, resulting in more available resin, as observed for particles from MDP residues, did not influence the increase in the IB of the panels, as reported in the literature (Moslemi 1974, Maloney 1993).

The average values of face screw withdrawal (FSW) ranged from $466 \mathrm{~N}$ (MDF) and $1183 \mathrm{~N}$ (Pinus). All the treatments produced from the residues had average values of FSW statistically lower than the control panels of Pinus. No treatment, including the control panels, met the minimum requirement of $1200 \mathrm{~N}$ as established by ABNT-NBR 14810-3: 2006. Regarding edge screw withdrawal (ESW), average strength values ranged from $341 \mathrm{~N}$ (MDF) to $1139 \mathrm{~N}$ (Pinus). All panels produced with residues were statistically lower in ESW than the Pinus control panels. No treatment, including the control panels, met the minimum requirement of $1200 \mathrm{~N}$ as established by ABNT-NBR 14810-3:2006.

Regarding edge screw withdrawal (ESW), average values ranged from $341 \mathrm{~N}$ (MDF) to 1139 $\mathrm{N}$ (Pinus). All panels produced with residues and mixtures showed statistically lower mean than the Pinus control panels. Only panels produced with residues of timber and the control presented average ESW values above the minimum requirement of $800 \mathrm{~N}$ as established by ABNT-NBR 14810-3:2006. It should be noted that the variations in the values of the bulk density of the materials analyzed did not directly influence the results of screw withdrawal. Moslemi (1974) and Maloney (1993) argue that panels produced with higher specific gravity or from materials with lower bulk density have higher compression ratios that result in panels with greater resistance to screw withdrawal. These results were not confirmed in this study.

There is the possibility of using the residues from this research as the inner layer of MDP panels as fillers, as they reach satisfactory values of perpendicular traction, an important property for the material of the inner layer. This assertion is corroborated by the fact that the rupture of this test occurs in the inner layer of the test specimen, so the recorded load reflects the resistance of this region. The treatments that obtained minimum standard requirements and therefore qualify for this purpose were the treatments MDP, plywood, timber and mixture of residues.

\section{CONCLUSIONS} MDP.

The wood present in construction and demolition wastes has potential for use in the production of 
The panels produced with timber residues presented the best results among the residues, satisfactory when compared to the Pinus control panels. This is an important result in view of the higher volume of this type of material in the total of construction and demolition waste collected by the recycling company.

The treatments of MDP, plywood, timber and the mixture in equal parts of residues, can be used as MDP panels inner layer filler, because they have satisfactory internal bond results.

From these results, it is recommended to carry out studies considering other process variables, in order to improve mechanical properties such as MOE and MOR in static bending.

\section{REFERENCES}

Alves, L.S. 2013. Aproveitamento de resíduos de empresas moveleiras da região de São José do Rio Preto para confecção e avaliação de painéis aglomerados. Master Thesis, Universidade Estadual Paulista, Ilha Solteira, Brasil.

Abrelpe. 2016. Associação Brasileira de Empresas de Limpeza Pública e Resíduos Especiais Panorama dos Resíduos Sólidos no Brasil 2015. São Paulo, Brasil.

Associação Brasileira de Normas Técnicas. ABNT. 1983. Carvão vegetal - ensaios físicos determinação da massa específica - densidade a granel. ABNT-NBR 6922. 1983. Rio de Janeiro, Brasil.

Associação Brasileira de Normas Técnicas. ABNT. 2006. Associação Brasileira de Normas Técnicas - Chapas de madeira aglomerada - parte 2 - requisitos. ABNT-NBR 14810. 2006.

Associação Brasileira de Normas Técnicas. ABNT. 2006. Associação Brasileira de Normas Técnicas - Chapas de madeira aglomerada - parte 3 - métodos de ensaio. ABNT-NBR 14810. 2006.

Candan, Z.; Akbulut, T. 2015. Physical and mechanical properties of nanoreinforced particleboard composites. Maderas. Ciencia y tecnología 17(2): 319-334.

CONAMA. 2002. Conselho Nacional do Meio Ambiente -Resolução $n^{\circ} 307$, de 5 de julho de 2002. Estabelece diretrizes, critérios e procedimentos para a gestão dos resíduos da construção civil. Diário Oficial da União, Brasília, Brasil.

Cochran, K.M.; Townsend, T.G. 2010. Estimating construction and demolition debris generation using a materials flow analysis approach. Waste Management (30):2247-2254.

European Standard. EN. 2002. Determination of modulus of elasticity in bending and of bending strength. EN 310. 2002.

European Standard. EN. 2003. European Standard. Particleboards - specifications. EN 312. 2003.

European Standard. EN. 2002. European Standard. Determination of swelling in thickness after immersion in water. EN 317. 2002.

European Standard. EN. 2002. European Standard. Determinação da resistência à tração perpendicular às faces da placa. EN 319. 2002. 
European Standard. EN. 1993. European Standard. Determination of moisture content. EN 322. 1993.

European Standard. EN. 1993. European Standard. Determination of density. EN 323. 1993.

Hossain, M.U.; Poon, C.S. 2018. Comparative LCA of wood waste management strategies generated from building construction activities. Journal of Cleaner Production (177): 387-397.

Karak, T.; Bhagat, R.M.; Bhattacharyya, P. 2012. Municipal solid waste generation, composition, and management: The World scenario. Critical Reviews in Environmental Science and Technology (42): 1509-1630.

Laquatra, J.; Pierce, M. 2004. Waste management at the residential construction site. Cityscape: A Journal of Policy Development and Research 30(2): 67-89.

Lykidis, C.; Grigoriou, A. 2008. Hydrothermal recycling of waste and performance of the recycled wooden particleboards. Waste management (28): 57-63.

Maloney, T.M. 1993. Modern particleboard \& dry-process fiberboard manufacturing. $2^{\text {nd }}$ ed. Miller Freeman Inc, San Francisco, United States.

Melo, R.R.D.; Stangerlin, D.M.; Sousa, A. P. D.; Cademartori, P. H. G. D.; Schneid, E. 2015. Physical mechanical properties of wood-bamboo particleboard. Ciência Rural, 45(1), 35-42.

Miranda, L.F.R.; Angulo, S.C.; Careli, E.D. 2009. Recycling of construction and demolition waste in Brazil: 1986-2008. Ambiente Construido 9(1): 57-71.

Moslemi, A.A. 1974. Particleboard. Southern Illinois University Press. London.

Nourbakhsh, A.; Ashori, A. 2010. Particleboard made from waste paper treated with maleic anhydride. Waste Management \& Research (28): 51-55.

Saez, P.; Del Rio Merino, M.; Amores, C.; Gonzalez, A. 2011. European legislation and implementation measures in the management of construction and demolition waste. The Open Construction and Building Technology Journal (5): 156-161.

Shen, L.Y.; Tam, V.W.Y.; Tam, C.M.; Drew, D. 2004. Mapping approach for examining waste management on construction sites. Journal of Construction and Management 130(4): 472-481.

Vale, A.T.; Mendes, R.M.; Amorim, M.R. S.; Dantas, V.F.S. 2011. Potencial Energético da Biomassa e Carvão Vegetal do Epicarpo e da Torta de Pinhão Manso (Jatropha curcas). Cerne 17(2): 267-273.

Vital, B.R.; Haselein, C.R.; Della Lucia, R.M. 1992. Efeito da geometria das partículas nas propriedades das chapas de madeira aglomerada de Eucalyptus grandis (Hill ex-Maiden). Árvore 16(1): 88-96.

Weber, C. 2011. Estudo sobre viabilidade de uso de resíduos de compensados, MDF e MDP para produção de painéis aglomerados. Master Thesis. Universidade Federal do Paraná, Curitiba, Brasil.

Weber, C.; Iwakiri, S. 2015. Utilization of waste of plywood, MDF and MDP for the production of particleboards. Ciência Florestal 25(2): 405-413.

Yang, T. H.; Lin, C. J.; Wang, S. Y.; Tsai, M. J. 2007. Characteristics of particleboard made from recycled wood-waste chips impregnated with phenol formaldehyde resin. Building and Environment 42(1): 189-195. 
Yuan, H.; Shen, L. 2011. Trend of the research on construction and demolition waste management. Waste Management (31): 670-679. 